\title{
The Evolving Disclosure Landscape: How Changes in Technology, the Media, and Capital Markets Are Affecting Disclosure
}

\author{
GREGORY S. MILLER*AND DOUGLAS J. SKINNER
}

\section{ABSTRACT}

Recent changes in technology and the media are causing significant changes in how capital markets assimilate and respond to information. We identify important themes in the disclosure literature and use this as a framework to discuss the conference papers that appear in this volume. These papers examine how managers' disclosure practices are being affected by changes in technology, the media, and capital markets. While this work makes important progress, we discuss how continuing technological change and the emergence of new forms of media offer further opportunities for research on the role of disclosure in capital markets.

JEL codes: G14; M41

Keywords: conference calls; disclosure; media

\section{Introduction}

Over the last two decades, the disclosure literature has emerged as one of the most important areas in accounting research. Interest in this area has been fueled by a growing realization among researchers that the ways

\footnotetext{
*University of Michigan, Ross School of Business; ${ }^{\dagger}$ University of Chicago, Booth School of Business.

Accepted by Christian Leuz. We are grateful to Philip Berger, Christian Leuz, and Haresh Sapra for comments on a previous version.
} 
managers communicate information about their firms has meaningful effects on capital market outcomes. These issues have become even more critical in recent years as changes in information technology, the media, and securities markets interact to affect the ways information about firms is produced, disseminated, and processed. It is clear from talking to CFOs and other practitioners that managers spend considerable time thinking about how to manage their firms' disclosures and that managers believe their disclosure decisions have first-order value implications.

We provide a framework for characterizing disclosure research and use this framework to summarize and put into broader context five papers that were presented at the 2014 Journal of Accounting Research (JAR) conference and that appear in this issue. Our goal in discussing these papers is to show how they fit into the preexisting literature and the framework we present, not to provide a detailed critique of each paper. We also provide suggestions for future research.

The conference theme was "Disclosure, the Media, and Capital Markets," and its aim was to bring together papers that examine how recent changes in technology, capital markets, and the media affect and are affected by firms' disclosure policies. These changes include:

- The way firms file and report information to regulatory agencies. The U.S. Securities and Exchange Commission (SEC) now requires firms to file using EDGAR, which effectively provides real time access to $10-\mathrm{K}$, $10-\mathrm{Q}$, and filings required by the agency. The SEC has also mandated the use of XBRL, which tags financial statement data electronically and so facilitates investors' ability to process detailed financial statement information.

- The way the media processes and disseminates information about firms, including the use of machine-driven algorithms that gather and disseminate news on a continuous basis in real time.

- The emergence of Big Data.

- The emergence of social media and its use by companies as part of their disclosure process, as well as the effect of social media more broadly on how managers manage the information environment of their firms given the interactive nature of these platforms.

- The increasing mobility and declining cost of computing devices with Internet connectivity and the accompanying increased penetration of these devices among the population at large.

- The way technology affects how capital markets process and respond to news about firms. The last decade has seen the emergence of highfrequency trading, dark pools, and other changes in the way price formation occurs in capital markets.

While these changes affect the way that information is produced, disseminated, processed, and traded on, the underlying economic forces that affect disclosure continue to be important. At the same time, new forces (such as social media and increased mobility) are emerging, and these forces are 
likely to change disclosure in important ways. To better understand these changes, it is useful to think about the disclosure literature as addressing three broad research questions.

First, researchers seek to understand the basic decision to disclose information: why firms voluntarily disclose information that is not mandated by regulators. Under this heading researchers look to explain how managers exercise their discretion over what to disclose and when to disclose it as well as the consequences of those decisions, which usually means whether there are beneficial capital market effects. For example, the earnings guidance literature is really about why managers provide earnings news early, in advance of the mandated announcement date, and how those decisions affect capital market outcomes.

Second, researchers seek to understand how managers choose to disseminate information about their firms. Research on dissemination addresses the mechanism or channel managers use to release information about their firms and whether dissemination affects capital market outcomes such as market liquidity, the firms' investor base, etc. This research also addresses the role of the media, both conventional and social, in disseminating information, as well as whether the media creates additional content that adds to or otherwise affects the information content of firm disclosures. Research questions in this area are evolving as a result of changes in technology and the media. For example, the emergence of high-frequency trading has made the speed and mechanics of dissemination increasingly important, while the emergence of social media means that firms' communications with investors are more interactive (as opposed to firms simply disseminating information to a passive audience).

Third, research addresses strategic aspects of disclosure, including whether managers' disclosure strategies are designed to "slant" news about firm performance in a particular way. For example, managers can use disclosure to complement financial reporting strategies that are designed to portray information about firm performance in a positive light, as when managers call on analysts who are more likely to be favorable during conference calls or seek to report adverse earnings news in periods when investors are paying less attention.

With this structure in mind, the following sections summarize the conference papers in the context of a broader discussion of the disclosure literature. Our goal is to help readers see how the papers fit into the disclosure literature in the hopes of generating future research that continues to explore these issues. In some ways, these papers represent a first step in understanding emerging forces in disclosure such as the role of social media and the increased penetration of mobile devices.

This discussion should in no way be construed as a comprehensive review of the literature. Instead, the goal is to identify some useful themes in the literature, link them to the conference papers, and explore implications for future research. 


\section{Conference Call Research}

When firms began to use conference calls to discuss their results during the 1990s, these calls were viewed as a new form of voluntary disclosure because: (i) not all firms held conference calls, and (ii) firms seemed to be using these calls to increase disclosure (Frankel, Johnson, and Skinner [1999], Tasker [1998]). Tasker's [1998] main prediction was that managers were more likely to use conference calls when their financial statements were relatively less informative about their firms' business and operations. Consistent with this, she finds that firms whose value depends relatively more on innovative and speculative activities were more likely to use conference calls. Frankel, Johnson, and Skinner [1999] find that firms that held conference calls were larger, more profitable, and more heavily followed by analysts than other firms, characteristics that are often associated with higher levels of disclosure.

Frankel, Johnson, and Skinner [1999] also examine whether conference calls provide information to investors beyond that available from the accompanying press releases, and so increase disclosure. Consistent with managers releasing new information during conference calls, these authors found that prices and volumes increased during the time of the calls, which were typically held after the accompanying press release had been disseminated. This raised questions about whether conference calls, which at the time were only available to certain analysts and other invited participants, were a form of selective disclosure.

This early research on conference calls exemplifies a "causes and consequences" pattern commonly followed by research on new forms of voluntary disclosure. That is, research examines why managers adopt a new disclosure practice as well as the capital market consequences of that practice. The underlying goal is to understand the costs and benefits of each innovation in disclosure. ${ }^{1}$

Before SEC Regulation FD came into force in October 2000, firms could choose whether to limit access to conference calls to a small group of participants, usually large institutional investors and security analysts who followed the firm ("closed calls"), or make closed calls available to any investors who might be interested ("open calls"). This choice tells us about how widely managers chose to disseminate information about their firms. Bushee, Matsumoto, and Miller [2003] investigate the determinants and effects of this decision, and find that firms with relatively more shareholders and relatively fewer institutional holders were more likely to open their conference calls. This suggests that the nature of the firm's investor base helps determine how widely its managers choose to disseminate information.

\footnotetext{
${ }^{1}$ Early research on earnings guidance follows this pattern. During the 1970s and 1980s, managers issued earnings forecasts infrequently, so researchers were interested in the forces that led some managers to provide forecasts while others did not, as well as the market effects of providing the forecasts (Patell [1976], Penman [1980], Lev and Penman [1990]).
} 
After Regulation FD led to the widespread use of open conference calls, researchers began to examine more nuanced aspects of the way conference calls were managed, including factors that affect the effectiveness of conference calls and how the management of calls was affected by the underlying news being conveyed. Matsumoto, Pronk, and Roelofsen [2011] examine more than 10,000 conference calls over 2003 to 2005 and find that the Q\&A segment of the call is generally more informative than the management presentation segment, especially for firms with greater analyst following and for which the earnings news being discussed was relatively poor.

An important and more general question in disclosure is whether managers strategically manage the way firm performance (earnings news) is disclosed, particularly whether managers differentially manage the disclosure of good and bad news. This line of research goes back to Skinner's [1994] findings that there is a strong asymmetry in the extent to which managers pre-announce earnings news (managers are significantly more likely to pre-announce adverse earnings news than other news), and extends more generally to accounting researchers' interest in how managers' accounting and disclosure decisions are affected by firm performance. Accounting researchers have long been interested in whether earnings are managed to shape investors' perceptions of firm performance (e.g., see the large literature on income smoothing) as well as how managers' reporting choices are related to their incentives to characterize news in a particular way (McVay [2006], Schrand and Walther [2000]).

The more general point to be made here is that managers' financial reporting and disclosure decisions are likely to form part of an overall financial reporting strategy designed to convey managers' views about how well the firms' overall operating and business strategies are being achieved. Further, it seems likely that the firm has an overall strategy for all of its financial decisions, so that financial reporting and disclosure decisions are integrated with decisions about capital structure and payout policy. In spite of this, most research tends to view these as separate decisions-that is, accounting decisions are seen as distinct from disclosure decisions, and we generally do not consider how these decisions relate to financing or payout decisions. Better understanding how managers integrate these decisions seems like a useful avenue for future research.

Research on conference calls now focuses on how managers use conference calls strategically to characterize firm performance in a more favorable light. Mayew [2008] examines whether managers use their ability to decide who asks questions on calls to manage analysts' questions, and finds that managers are more likely to call on analysts who have more favorable recommendations and so presumably will be less critical of management.

More recent research examines managers' speech during conference calls. Hobson, Mayew, and Venkatachalam [2012] show that nonverbal vocal cues extracted from managers' speech during conference calls can be used to detect deception by managers and that these cues predict subsequently reported accounting irregularities. Larcker and Zakolyukina 
[2012] use approaches developed in linguistics to analyze the words managers use during conference calls for signs of deceptive behavior, and show that deceptive language during conference calls is associated with accounting irregularities as well as stock price underperformance.

The Allee and DeAngelis [2015] conference paper extends this line of research by examining how managers distribute "tone words" in conference call disclosures. Like Larcker and Zakolyukina [2012], this research extends a recent line of work that uses tools from linguistics to examine the tone of narrative disclosures such as the Management Discussion and Analysis (MD\&A; e.g., Li [2010], Loughran and McDonald [2011]). Tone words are words that managers use to convey a positive or negative picture of firm performance and prospects. Rather than simply counting tone words, Allee and DeAngelis [2015] observe that the information content of narrative disclosures is likely to depend on the placement of these words within documents and adopt a measure of where words are placed from the linguistics literature. Allee and DeAngelis refer to this as tone "dispersion." For example, if managers were interested in emphasizing positive news about firm performance and de-emphasizing negative news (as we generally suppose), they might spread positive tone words throughout their prepared remarks but place negative tone words close together.

This has an interesting similarity to financial reporting practices, such as managers' tendency to engage in "big bath" reporting, the strategic placement and description of items within the income statement (McVay [2006]), and the strategic use of earnings benchmarks (Schrand and Walther [2000]).

Allee and DeAngelis [2015] report a number of useful findings. First, the authors find significant persistence in tone dispersion through time, indicating that it is likely related to firm and/or manager characteristics. Second, the authors find that managers use dispersion strategically: the dispersion of negative and positive tone words is related to reported performance, which suggests that managers use dispersion to manage how investors perceive and respond to earnings news. Finally, the authors show that managers' strategic use of tone words affects analysts' responses (as measured by the questions they ask) and the market response to the news. In this sense, this work complements papers such as Larcker and Zakolyukina [2012], which show that cues extracted from the language management uses during conference calls predict performance. More generally, it shows further evidence of strategic communication by management.

\section{Disclosure and Social Media}

We usually think of disclosure channels such as press releases and conference calls as a way for managers to manage their firms' information environments by providing external constituents with better and more timely information relevant to valuation. However, with the advent of social 
media, firms have lost a certain amount of control of their information environments in ways that are difficult to predict and manage.

While it has always been the case that the conventional media creates content about firms (as when reporters write investigative pieces), this is relatively unusual. Miller [2006] shows that the media identifies almost one-third of frauds before they are announced by the firm. However, the 75 articles he identifies over a 17-year period represent a small portion of total press coverage. The arrival of social media platforms such as Facebook and Twitter means that many more actors can make their views about the firm known and disseminate those views widely, potentially creating adverse consequences for firms, especially if the actors that engage on social media are relatively uninformed. In addition to providing more sources of news, some observers argue that proliferation of social media will reduce interest in and resources available to more conventional media, weakening its role while social media becomes more important (Lau and Wydick [2014]).

So far, there is relatively little work on how firms use social media. Blankespoor, Miller, and White [2014] examine how firms use Twitter to disseminate firm news by providing links to press releases in their Twitter feeds. They use the term "direct-access information technology" (DAIT) because, unlike conventional disclosures that rely on users taking actions to access disclosures, Twitter allows companies to "push" disclosures directly to users and so directly disseminate news, as opposed to the more conventional approach of relying on users to access content that is disseminated through media outlets.

Lee, Hutton, and Shu [2015] explore a different aspect of social media by exploring how firms use social media to manage product recalls. Product recalls represent "crises" that affect the firms' product market in potentially significant ways, especially if managed poorly. Product recalls naturally create uncertainty in the minds of a large group of the firms' customers as well as the public at large, and typically result in negative stock price reactions because of their adverse product market effects.

The authors examine how firms use different forms of social media, including Facebook and Twitter, to manage the flow of information about the recall in an attempt to minimize the associated adverse effects. There are at least two potentially countervailing effects. First, firms can use social media to quickly inform customers and the public at large about the recall, minimizing the extent to which rumors and misinformation increase the scope of the crisis (e.g., they can respond directly to negative tweets or Facebook posts, including some that may be false or misleading). Second, however, disseminating information about the recall is a double-edged sword in that it can also exacerbate the crisis by spreading the news to a wider audience, potentially helping the news to go "viral." The availability of interactive social media platforms such as Facebook and Twitter means that users can themselves comment on and disseminate news about the recall, potentially increasing the spread of negative sentiment, including misinformation. The net effect of these different forces is hard to assess ex ante. 
The authors' results suggest that the net effect of social media is to mitigate the adverse effect of the recall. First, the authors report that the stock price response to product recalls is less negative for firms that use interactive social media such as Facebook and Twitter. Second, the authors look specifically at how the use of social media by the firm and other users affects the response to the recall. They find that the negative response to the recall is exacerbated by the extent to which other users disseminate news about the recall (as measured by the number of tweets) but that this effect is mitigated by the extent of the firm's efforts to address the problem (as measured by the number of tweets sent by the firm). Overall, the evidence suggests that, if properly managed, firms can engage users and customers through social media to mitigate the adverse effect of "crises" associated with product recalls, a result that potentially extends to other types of corporate events. For example, one can imagine firms engaging users on social media to mitigate investor uncertainty created by large negative earnings surprises, a more direct and interactive form of disclosure than available through Q\&A interactions on conference calls.

The SEC has recently provided guidance that explicitly allows firms to use social media to disseminate corporate news. ${ }^{2}$ Along with the tremendous growth and penetration of social media, this makes it likely that social media will become an increasingly important component of firms' disclosure strategies.

Social media seems like an important new strand of the literature given its increasing use by a large cross section of society and the potential for users to create and disseminate their own content (it may not be news) about firms. This represents a new question in the literature because previous disclosure platforms preclude or at least limit the extent to which investors at large can respond to and disseminate their own views about firms.

\section{Mobility}

An important factor in the growth of social media is the increased availability of mobile communication devices such as smart phones that have Internet connectivity and so allow users to interact on social media in real time. The increasing penetration of these devices also enables users to acquire, communicate, and trade on information about firms, and so, like social media, has potentially significant effects on firms' information environments and capital market trading activity. The goal of Brown, Stice, and White [2015] is to provide preliminary evidence on these effects.

To examine the effect of mobile communications, Brown, Stice, and White [2015] exploit a set of laws that provide exogenous variation in users'

\footnotetext{
${ }^{2}$ See http://www.sec.gov/News/PressRelease/Detail/PressRelease/1365171513574\#.VM9_ R3u8rfc.
} 
ability to use mobile devices. Specifically, these authors use the implementation of state-level distracted driver laws (which restrict the use of mobile devices by drivers in cars) to examine the effects of the use of mobile devices on the collection and diffusion of local information about firms, as well as trading in these firms. The authors hypothesize that local investors use mobile devices to gather and distribute information about local companies as well as to trade on this information. To test this, the authors examine whether the introduction of distracted driving laws affects information flows and trading in local firms. This is a powerful setting because the authors can examine short windows of time around the introduction of these laws (including intraday effects), and because the timing of the introduction of these laws is plausibly exogenous with respect to corporate disclosure decisions.

The authors report a number of interesting findings. First, consistent with the use of mobile technology to access local information about local firms, the authors find that Google search volume declines at the time these laws are introduced and that the effect is less pronounced when laws allow the use of hands-free technology. Second, the authors find a significant decline in trading volume for local stocks after the introduction of distracted driving laws. This effect is more pronounced when local users have longer commutes and when commute times overlap with periods when exchanges are open. The authors find additional effects for spreads and prices that are related to the volume effects.

Given the authors' setting and research design, it is difficult to imagine a story under which the types of reverse causality or correlated omitted variables explanations that we normally worry about in disclosure research are at play. This is especially true of the intraday results, which show a decline in trading activity during commuting times relative to other times during the day and relative to states that do not have these laws. The results extend recent work that demonstrates the importance of local information flows to smaller, local investors and how this influences trading, especially for those stocks for which local information and trading is likely to be more important (Engelberg and Parsons [2011], Peress [2014]). Brown, Stice, and White [2015] show that local investors, who are likely to have greater access to local information about firms in their locales, use mobile devices to collect and disseminate this information, which in turn affects trading activity in these stocks. Overall, the authors' findings show that the increased penetration of mobile technology affects local information acquisition and trading, and that there is a direct effect of this technology on these outcomes.

\section{Media}

Because disclosure research often relies on the media to identify firm disclosures, it implicitly includes the impact of media coverage in measuring the effects of disclosure. Early management earnings forecast studies 
rely on The Wall Street Journal to obtain forecast data (e.g., Imhoff [1978], Penman [1980]). In spite of this reliance on the media, until recently there has been relatively little research that explicitly examines the actions, incentives, or impact of the media.

Early considerations of the role of the press were often incidental to the broader research question. Foster [1979] examines the market response to Barron's publication of fundamental accounting analyses performed by Abraham Briloff. This paper was motivated by anecdotal arguments that negative market responses for firms discussed in these articles was a form of market inefficiency. Foster [1987] follows up on this study, but still is unable to provide a clear explanation for the market reaction. While both studies include some discussion of the role of Barron's in disseminating Briloff's analyses to a wider audience, they do not explicitly examine the role of press coverage. In this way, the media literature is similar to other literatures that we discuss: researchers first began using it either as a tool in their research or as an incidental part of the study. It is now clear that the role of the media is of interest in its own right, especially if it does more than simply disseminate news, as is possible in the Briloff example. Research on the media has taken much longer than most other streams of the disclosure literature; for example, the conference call and earnings forecast literatures developed in a relatively short amount of time. ${ }^{3}$ While some research on the media has occurred, this area is still relatively undeveloped.

The earliest empirical work in accounting (of which we are aware) to explicitly examine the determinants of media coverage-by Thompson, Olsen, and Dietrich [1987]—uses The Wall Street Journal Index to examine the types of firm news reported, with the goal of helping researchers understand the determinants of the news coverage they were relying on to obtain firm disclosures. Thompson, Olsen, and Dietrich [1987] find, among other things, that larger firms are more likely to be covered by The Wall Street Journal, which is early evidence of the media's tendency to cover larger firms to a greater extent than smaller firms. However, the literature quickly evolved to follow two related paths: whether the media plays a monitoring role in capital markets and whether media coverage in and of itself affects stock prices.

The first stream of literature argues that the media monitors management by identifying management malfeasance through original analysis or by bringing attention to malfeasance first identified by intermediaries such as analysts. Miller [2006] examines whether the media identifies accounting irregularities that eventually lead to SEC censure via Accounting and Auditing Enforcement Releases (AAERs). This study shows that the press often identifies such malfeasance and does so well before other intermediaries. However, Miller also finds that the press is more likely to play this

\footnotetext{
${ }^{3}$ It could be that this slow development was due to difficulties in understanding the institutional features of "the media," with its many different press outlets and roles, as well as to the difficulty of obtaining large-scale measures of press coverage.
} 
"watchdog" role for large firms and more salacious frauds, both of which will likely attract greater readership (and revenues).

Core, Guay, and Larcker [2008] examine whether the press monitors CEO compensation. They find that the press does identify excess compensation, and that it is more likely to report on firms with large stock option exercises, which the authors argue can be sensationalized. They also find that firms do not change compensation in response to press coverage, suggesting that the monitoring is not effective. A more recent study by Kuhnen and Niessen [2012] finds that firms do reduce stock option grants to CEOs when there is negative coverage of CEO compensation.

Dyck, Volchkova, and Zingales [2008] examine Anglo-American press coverage of Russian firms that is based on information provided by a hedge fund (and so not due to press analyses). They find that adverse press coverage leads to improvements in governance and attribute this to the broader international dissemination of the governance problems that pressures the firm and Russian regulators to reform.

Overall, these papers suggest that the press serves a monitoring role, both by creating content and by disseminating content generated by others. ${ }^{4}$ We see this as an important finding, but more research is warranted to generalize and extend these findings.

The second stream of literature-which includes Sant and Zaman [1996], Bushee et al. [2010], Engelberg and Parsons [2011], and Drake, Guest, and Twedt [2014] - examines the role of the media in disseminating information to a wider audience. These studies attempt to minimize or control for new information to isolate dissemination effects of the media. These studies focus almost exclusively on the impact on prices in financial markets. A related set of studies do not explicitly refer to dissemination, but use a related firm visibility argument (Merton [1987]) to examine whether the press increases the "visibility" of firms. These studies also find that press coverage impacts pricing and market activity (Barber and Odean [2008], Fang and Peress [2009]). ${ }^{5}$ Collectively, these studies indicate that the press also plays an important role in dissemination.

\footnotetext{
${ }^{4}$ The press did not create the information in the Dyck, Volchkova, and Zingales [2008] paper; that information was created by a hedge fund combining public and private information. As highlighted in Foster [1979], it is difficult to determine exactly where on the continuum information moves from being previously "private" to "public," however it seems reasonable to argue that this information was likely not broadly known by readers. Further, these articles, as well as those in Miller [2006] and Core, Guay, and Larcker [2008], were written to put the information into a broad context with other information regarding the firm. The thesis in these long press articles likely combines previously available information in a way that was new to the vast majority of readers-again leading to the question of whether this is new "public" information.

${ }^{5}$ This visibility role is also supported by several studies that examine television coverage (Fehle, Tsyplakov, and Zdorovtsov [2005], Kim and Meschke [2011], Engelberg, Sasserville, and Williams [2012]).
} 
Dai, Parwada, and Zhang [2015] combine these streams of research by examining the monitoring role of the press when it disseminates information in SEC filings regarding managers' insider stock sales. They argue that, while dissemination through the press does not create new information (SEC filings are publicly available through EDGAR), it does distribute the news to a wider audience and thereby creates "discipline via dissemination." They find that wider dissemination reduces managers' future trading and the profitability of the trades. They show that the disciplinary effect occurs through three mechanisms: reduction of information asymmetry, fear of subsequent litigation, and the capital at risk.

By demonstrating changes in managerial behavior, Dai, Parwada, and Zhang [2015] add to our understanding of the press as a monitor. While prior studies explicitly identify situations where the press either creates information or disseminates information created by other specialists (a hedge fund), this paper shows that the monitoring role can be fulfilled even when the press simply highlights nominally "public" existing information, which is generally presented without any contextual analyses. This evidence helps to establish the media as a monitor.

This paper extends the dissemination literature by showing that media coverage affects subsequent manager actions. Previous papers focus largely on the market response to broader dissemination. Those papers show that market participants respond when information is more widely distributed, but is largely silent on whether greater dissemination changes the actions of other stakeholders. By showing changes in managers' subsequent actions, this paper deepens our understanding of the role of dissemination to players beyond the financial markets (although admittedly the impacts shown are based on their actions within financial markets).

While Dai, Parwada, and Zhang [2015] provide meaningful insights on both the monitoring and dissemination roles of the media, we know less about the role of the media than we do about the role of other intermediaries (analysts) and monitors (auditors or institutional investors). Future research would benefit from a more complete theory of the role of the media in financial markets. Jensen [1979] argues that the media exists primarily to entertain, and predicts that it provides little informational value but instead chooses to report content that increases readership. Broadly consistent with this, Gentzkow and Shapiro [2010] provide evidence that media outlets "slant" their coverage of politics to cater to the political views of their local readers. This seems inconsistent with evidence that shows that the media plays monitoring and dissemination roles although evidence of biases in media coverage support this view. Miller [2006] and Core, Guay, and Larcker [2008] provide arguments that could help further develop a theory of the media.

One promising approach is to consider the media's interaction with other players in financial markets, such as analysts, auditors, investors, etc. Early work such as Sant and Zaman [1996] (analysts), Miller [2006] (analysts and auditors), and Dyck, Volchkova, and Zingales [2008] (hedge 
funds) all provide some empirical evidence of interactions between the media and these other groups. While Dai, Parwada, and Zhang [2015] expand this to the impact on managerial actions, this area is still relatively undeveloped. Future studies will need to provide a fuller understanding of the institutional relationships between the media and these other capital market participants in order to develop cleaner models. Because the media has both overlapping and differing incentives from these other players in financial markets, a fuller understanding of the media and its relations to these other players would contribute significantly to our overall understanding of information flow in financial markets.

Recent years have seen a sharp increase in the amount of published work on the role of the media (Tetlock [2014]). This increased interest is promising. As Tetlock points out, much of this work is driven by new data sources such as RavenPack (which was also used by Dai, Parwada, and Zhang [2015]). These new data sources offer opportunities but it will also be important for researchers to be sure that we draw from a wide range of sources that represent the full spectrum of the media. As an example, the RavenPack product commonly used by researchers is limited to Dow Jones sources (and Dai, Parwada, and Zhang [2015] only use news alerts). Thus, it only captures dissemination by a single outlet, albeit an important one. This may not be an issue in the current study, but it is important that researchers are aware of these types of limitations. Further, it will be important not to over-generalize the findings from any single source of data to all forms of media. Previous research shows that media outlets have a range of incentives that can affect the way they collect, cover, and portray news about firms. For example, prior research shows that some (but not all) media outlets' coverage or treatment of an issue may be influenced by the possibility that the covered firms will adjust their advertising (Reuter and Zitzewitz [2006], Gurun and Butler [2012]). Similarly, as discussed above, evidence that news outlets slant coverage to match readers' tastes and preferences (at least for political coverage) also means we have to be cautious about relying on limited sources of media coverage.

\section{Political Forces and Disclosure}

A large literature examines the impact of government on accounting information, but most of that literature examines how changes in regulation affect disclosure and the associated capital market outcomes (e.g., the effect of SEC Regulation FD or the Sarbanes Oxley legislation). These papers generally examine whether a regulatory change achieves its objective as well as whether there are any unintended consequences. The impact of regulation is clearly an important research topic, which justifies the large amount of research in this area. However, the government likely influences capital markets in more subtle ways as well, and these deserve more attention.

Watts and Zimmerman's [1986] "political cost hypothesis" is an early attempt to understand the role of government beyond the direct effects 
of regulation. Watts and Zimmerman argue that the fear of government scrutiny and its associated costs or the desire for wealth transfers in the regulatory process provides managers with incentives to manage earnings downwards. There is some empirical support for these predictions (Wong [1988], Cahan [1992], Key [1997], Han and Wang [1998]).

While this literature shows that the political process provides managers with incentives to manage reported earnings, it generally does not consider whether managers attempt to manage their firms' information environments in other ways. Patten and Trompeter [2003] examine the response of chemical firms to a deadly leak in a Union Carbide plant in India. While they find that managers of chemical firms manage earnings downward during this period of high scrutiny, they also show that firms with higher levels of voluntary disclosure exhibit less downward manipulation. This suggests that voluntary disclosure also affects firms' relations with the government and the associated political costs. Eng and Mak [2003] further investigate the relation between voluntary disclosure and the government by showing that higher governmental investment in Singaporean firms is associated with greater levels of disclosure. This work suggests that political and regulatory incentives may affect firms' disclosure choices, but this area remains relatively undeveloped.

A closely related stream of research examines the accounting or business decisions of government controlled entities and how they relate to political incentives. Perhaps closest to the political cost hypothesis, Kido, Petacchi, and Weber [2012] examine financial statement manipulation by state governments in the United States to more favorably portray their economic health during election years. These authors show that states make discretionary choices that generally increase current reported earnings, which presumably helps incumbent politicians gain reelection. Several papers on government-owned banks show similar patterns of behavior in loan decisions. For example, government banks increase lending during election years (Dinc [2005]) and change their lending in election years based on election outcomes and the strength of local political parties (Sapienza [2004], Micco, Panizza, and Yanez, [2007]). Overall, this literature suggests that government-owned entities manipulate accounting information and take real actions to support their political interests. This raises the question of whether nongovernmental entities are likely to take similar steps in their own political interests.

Piotroski, Wong, and Zhang [2015] investigate the suppression of negative information before important political events in China. They predict that firms suppress bad news prior to and during important political events in China to avoid embarrassing important political patrons. Their findings support these predictions and hold for both state-owned firms, where a relatively direct mechanism and incentive for disclosure exists, and in non-stateowned firms that nominally should be freer from such influence. These actions suggest an attempt to strategically use disclosure not just to avoid government scrutiny or to support your current boss, but also to actively 
curry favor from political sources even for non-state-controlled firms. In showing that these firms skew their information environment, Piotroski, Wong, and Zhang [2015] relate to studies such as Leuz and Oberholzer-Gee [2006] and Chaney, Faccio, and Parsley [2011], which show that politically connected firms have more opaque information environments. Piotroski, Wong, and Zhang [2015] extend this literature by showing that the disclosure decisions may be strategically adjusted over time based on political needs, similar to the arguments made in the political cost literature.

In addition to contributing to the relatively limited literature on the direct influence of government on disclosure, this paper relates to the large literature on the impact of firm performance on disclosure. That idea is most fully developed in the earnings forecast literature. Early work in the area (Verrecchia [1983], Lev and Penman [1990]) argues that managers who are evaluated based on measures of performance such as earnings will manage the flow of information to external constituents to portray their performance more favorably, and so accelerate the release of good news by providing positive earnings forecasts. However, subsequent literature finds that other factors, such as fear of legal costs or reputational damage, provide incentives for managers to disclose negative news on a more timely basis than good news when managers know the information will be revealed (Skinner [1994], Kasznik and Lev [1995]).

These findings suggest that there is a rich and complicated interaction between disclosure and firm performance. If there is significant cost to withholding negative news that will soon become public, managers are likely to divulge this news on a timely basis. However, if there is some possibility that the bad news will not be revealed (perhaps because offsetting good news arrives before the end of the period), managers defer the revelation of bad news and accelerate the revelation of good news (Kothari, Shu, and Wysocki [2009]). Piotroski, Wong, and Zhang [2015] provide a setting where the important actors (in this case, politicians) benefit sufficiently from the deferral of bad news and there is not full ex post settling up.

Piotroski, Wong, and Zhang [2015] exploit the strong role of the government in China to demonstrate that politics affects firms' disclosure incentives. It would be useful for future research to consider whether governments in other economies play a similar role (see Ramanna and Roychowdhury [2010], for similar research in the U.S. setting). It would also be interesting to better understand the role of other actors in this process. For example, did the press assist in this attempt to skew information regarding these firms or did it attempt to act as a monitor (as discussed in the above section on the media)? Was there a difference in coverage between domestic (and presumably politically connected) media and foreign media? What about other entities, such as auditors? Will the developing use of social media reduce firms' (and governmental entities') abilities to take these actions? 


\section{Conclusion}

We summarize five papers that collectively advance our understanding of the role of disclosure in financial markets in a number of important ways. This work enhances our understanding of how managers use conference calls to complement how they report and disclose firm performance; how social media changes the way that firms interact with investors as well as the public at large; how the increased use of mobile devices affects how investors collect and disseminate local information, which in turn affects trading activity, and deepens our understanding of the role of crucial actors outside the firm (the media and the government).

While the conference papers focus on how recent changes in technology and the media affect financial markets, they also extend existing strands of disclosure research. Both the earnings forecast and conference call literatures show how new forms of disclosure are initially adopted by only a few players in the market, but over time become more widely used. These papers provide evidence on new trends in disclosure that are likely to become more prevalent over time, and show how the emergence of new disclosure channels, such as social media, raises new research questions. For example, the emergence of social media not only provides firms with a new way of disseminating information, but also provides external users with the ability to create and disseminate their own content. This reduces firms' ability to tightly manage their information environments, which means they need to develop new disclosure strategies.

\section{REFERENCES}

Allee, K. D., And M. D. DeAngelis. "The Structure of Voluntary Disclosure Narratives: Evidence from Tone Dispersion.” Journal of Accounting Research 53 (2015): 221-39.

BARBER, B. M., AND T. ODEAN. "All That Glitters: The Effect of Attention and News on the Buying Behavior of Individual and Institutional Investors.” Review of Financial Studies 21 (2008): $785-818$.

BlankespoOR, E.; G. S. Miller; AND H. White. "The Role of Dissemination in Market Liquidity: Evidence from Firms' Use of Twitter." The Accounting Review 89 (2014): 79 112.

BROWN, N. C.; J. H. STICE; AND R. M. WhitE. "Mobile Communication and Local Information Flow: Evidence from Distracted Driving Laws." Journal of Accounting Research 53 (2015): 275 329.

Bushee, B. J.; J. E. Core; W. Guay; And S. J. W. Hamm. "The Role of the Business Press as an Information Intermediary." Journal of Accounting Research 48 (2010): 1-19.

Bushee, B. J.; D. A. Matsumoto; And G. S. Miller. "Open Versus Closed Conference Calls: The Determinants and Effects of Broadening Access to Disclosure." Journal of Accounting and Economics 34 (2003): 149-80.

CAHAN, S. F. "The Effect of Antitrust Investigations on Discretionary Accruals: A Refined Test of the Political-Cost Hypothesis." The Accounting Review 67 (1992): 77-95.

Chaney, P. K.; M. FACCIO; AND D. PARSLEY. "The Quality of Accounting Information in Politically Connected Firms." Journal of Accounting and Economics 51 (2011): 58-76.

Core, J. E.; W. GuAY; AND D. F. LARCKER. "The Power of the Pen and Executive Compensation." Journal of Financial Economics 88 (2008): 1-25. 
DAI, L.; J. T. PARWADA; AND B. ZHANG. "The Governance Effect of the Media's News Dissemination Role: Evidence from Insider Trading." Journal of Accounting Research 53 (2015): 331-66.

DINC, I. S. "Politicians and Banks: Political Influences on Government-Owned Banks in Emerging Markets." Journal of Financial Economics 77 (2005): 453-79.

Drake, M. S.; N. M. Guest; AND B. J. TwedT. "The Media and Mispricing: The Role of the Business Press in the Pricing of Accounting Information." The Accounting Review 89 (2014): 1673-701.

DycK, A.; N. VolchKova; And L. Zingales. "The Corporate Governance Role of the Media: Evidence from Russia.” Journal of Finance 63 (2008): 1093-135.

ENG, L. L., AND Y. T. MAK. "Corporate Governance and Voluntary Disclosure." Journal of Accounting and Public Policy 22 (2003): 325-45.

EngelberG, J. E., AND C. A. PARsons. "The Causal Impact of Media in Financial Markets." Journal of Finance 66 (2011): 67-97.

EngelberG, J. E.; C. Sasserville; And J. Williams. "Market Madness? The Case of Mad Money." Management Science 58 (2012): 351-64.

FAnG, L. H., AND J. PERESS. "Media Coverage and the Cross-Section of Stock Returns." Journal of Finance 64 (2009): 2023-52.

FeHLe, F.; S. TSYPLAKOV; AND V. ZdorovTsov. "Can Companies Influence Investor Behaviour Through Advertising? Super Bowl Commercials and Stock Returns." European Financial Management 11 (2005): 625-47.

FrAnKel, R.; M. JOHnSON; AND D. J. SkINNER. "An Empirical Examination of Conference Calls as a Voluntary Disclosure Medium.” Journal of Accounting Research 37 (1999): 133-50.

Foster, G. "Briloff and the Capital Market." Journal of Accounting Research 17 (1979): 262-74.

FOSTER, G. "Rambo IX: Briloff and the Capital Market." Journal of Accounting, Auditing and Finance 2 (1987): 409-30.

GentzKow, M., AND J. M. SHAPIRO. "What Drives Media Slant? Evidence from U.S. Daily Newspapers." Econometrica 78 (2010): 35-71.

Gurun, U. G., AND A. W. Butler. "Don’t Believe the Hype: Local Media Slant, Local Advertising, and Firm Value." Journal of Finance 67 (2012): 561-98.

HAN, J. C. Y., AND S. WANG. "Political Costs and Earnings Management of Oil Companies During the 1990 Persian Gulf Crisis.” The Accounting Review 73 (1998): 103-17.

Hobson, J. L.; W. J. Mayew; And M. Venkatachalam. "Analyzing Speech to Detect Financial Misreporting." Journal of Accounting Research 50 (2012): 349-92.

ImHOFF, E. A. "The Representativeness of Management Earnings Forecasts." The Accounting Review 53 (1978): 836-50.

Jensen, M. "Toward a Theory of the Press," in Economics and Social Institutions, edited by K. Brunner. Boston, MA: Martinus Nijhoff, 1979: 267-87.

KASZNIK, R., AND B. LEV. "To Warn or Not to Warn: Management Disclosures in the Face of an Earnings Surprise.” The Accounting Review 70 (1995): 113-34.

Key, K. G. "Political Cost Incentives for Earnings Management in the Cable Television Industry." Journal of Accounting and Economics 23 (1997): 309-37.

KIDO, N.; R. PETACCHI; AND J. WEBER. "The Influence of Elections on the Accounting Choices of Governmental Entities." Journal of Accounting Research 50 (2012): 443-76.

KIM, Y. H., AND F. MESCHKE. "CEO Interviews on CNBC." Working paper, Nanyang Technological University and University of Kansas, 2011.

Kothari, S. P.; S. SHU; AND P. D. WysOcki. "Do Managers Withhold Bad News?" Journal of Accounting Research 47 (2009): 241-76.

Kuhnen, C. M., AND A. Niessen. "Public Opinion and Executive Compensation." Management Science 58 (2012): 1249-72.

Larcker, D. F., AND A. A. Zakolyukina. "Detecting Deceptive Discussions in Conference Calls." Journal of Accounting Research 50 (2012): 495-540.

LAU, M., AND B. WYDICK. "Does New Information Technology Lower Media Quality? The Paradox of Commercial Public Goods." Journal of Industry, Competition and Trade 14 (2014): $145-57$. 
LeE, L. F.; A. Hutton; And S. Shu. "The Role of Social Media in the Capital Market: Evidence from Consumer Product Recalls." Journal of Accounting Research 53 (2015): 367-404.

LeuZ, C., AND F. OBerholzer-GEe. "Political Relationships, Global Financing, and Corporate Transparency: Evidence from Indonesia." Journal of Financial Economics 81 (2006): 411-39.

Lev, B., AND S. H. Penman. "Voluntary Forecast Disclosure, Nondisclosure, and Stock Prices." Journal of Accounting Research 28 (1990): 49-76.

LI, F. "The Information Content of Forward-Looking Statements in Corporate Filings-A Naïve Bayesian Machine Learning Approach.” Journal of Accounting Research 48 (2010): $1049-102$.

Loughran, T., And B. MCDONALD. "When Is a Liability NOT a Liability? Textual Analysis, Dictionaries, and 10-Ks." Journal of Finance 66 (2011): 35-65.

Matsumoto, D. A.; M. Pronk; And E. Roelofsen. "What Makes Conference Calls Useful? The Information Content of Managers' Presentations and Analysts' Discussion Sessions." The Accounting Review 86 (2011): 1383-414.

MAYEW, W. J. "Evidence of Management Discrimination Among Analysts During Earnings Conference Calls.” Journal of Accounting Research 46 (2008): 627-59.

McVAY, S. E. "Earnings Management Using Classification Shifting: An Examination of Core Earnings and Special Items.” The Accounting Review 81 (2006): 501-31.

Merton, R. C. "A Simple Model of Capital Market Equilibrium with Incomplete Information." Journal of Finance 42 (1987): 483-510.

Micco, A.; U. PAnizZA; And M. YañEz. "Bank Ownership and Performance. Does Politics Matter?" Journal of Banking and Finance 31 (2007): 219-41.

Miller, G. S. "The Press as a Watchdog for Accounting Fraud." Journal of Accounting Research 44 (2006): 1001-33.

PATELL, J. M. "Corporate Forecasts of Earnings per Share and Stock Price Behavior: Empirical Tests.” Journal of Accounting Research 14 (1976): 246-76.

Patten, D. M., AND G. Trompeter. "Corporate Responses to Political Costs: An Examination of the Relation Between Environmental Disclosure and Earnings Management." Journal of Accounting and Public Policy 22 (2003): 83-94.

Penman, S. H. "An Empirical Investigation of the Voluntary Disclosure of Corporate Earnings Forecasts." Journal of Accounting Research 18 (1980): 132-60.

PERESS, J. "The Media and the Diffusion of Information in Financial Markets: Evidence from Newspaper Strikes." Journal of Finance 69 (2014): 2007-43.

Piotroski, J. D.; T. J. WONG; AND T. Zhang. "Political Incentives to Suppress Negative Information: Evidence from Chinese Listed Firms.” Journal of Accounting Research 53 (2015): 405-59.

RAMANNA, K., AND S. ROYCHOWDURY. "Elections and Discretionary Accruals: Evidence from 2004." Journal of Accounting Research 48 (2010): 445-75.

REUTER, J., AND E. ZitZEWITZ. "Do Ads Influence Editors? Advertising and Bias in the Financial Media." Quarterly Journal of Economics 121 (2006): 197-227.

SANT, R., AND M. A. ZAMAN. "Market Reaction to Business Week 'Inside Wall Street' Column: A Self-Fulfilling Prophecy." Journal of Banking and Finance 20 (1996): 617-43.

SAPIENZA, P. "The Effects of Government Ownership on Bank Lending." Journal of Financial Economics 72 (2004): 357-84.

SCHRAND, C., AND B. WALThER. "Strategic Benchmarks in Earnings Announcements: The Selective Disclosure of Prior-Period Earnings Components." The Accounting Review 75 (2000): 151-77.

Skinner, D. J. "Why Firms Voluntarily Disclose Bad News." Journal of Accounting Research 32 (1994): 38-60.

TASkER, S. C. "Bridging the Information Gap: Quarterly Conference Calls as a Medium for Voluntary Disclosure." Review of Accounting Studies 3 (1998): 137-67.

Tetlock, P. C. "Information Transmission in Finance." Annual Review of Financial Economics 6 (2014): 365-84. 
Thompson, R. B.; C. Olsen; AND J. R. Dietrich. "Attributes of News About Firms: An Analysis of Firm-Specific News Reported in The Wall Street Journal Index." Journal of Accounting Research 25 (1987): 245-74.

VERRECCHIA, R. E. "Discretionary Disclosure." Journal of Accounting and Economics 5 (1983): 179-94.

WatTs, R. L., AND J. L. Zimmerman. Positive Accounting Theory. Englewood Cliffs, NJ: Prentice Hall, 1986.

WONG, J. "Political Costs and an Intraperiod Accounting Choice for Export Tax Credits." Journal of Accounting and Economics 10 (1988): 37-51. 